\title{
Urban resilience, the local and the politics of the Anthropocene: reflections on the future of the urban environment
}

\section{Lazaros Karaliotas and Giovanni Bettini}

Pre-print author copy - Published in:

Handbook of Cities and the Environment, Edited by Kevin Archer and Kris Bezdecny

\section{INTRODUCTION: A HUMAN PLANET, IN URBAN TIMES?}

Environmental discourses are increasingly scripted around two signifiers - the Anthropocene and urbanization - that mirror the profound reconfigurations that have shaken environmental thought and praxis. The concept of the Anthropocene elevates the human species into a geological force that is bringing about a planetary shift. The impacts of human activities, so the argument goes, have moved the Earth system away from the Holocene and into a new geological era, namely the Anthropocene (Crutzen and Stoermer, 2000, Steffen et al., 2007). If our geological époque is said to be that of "mankind," equally widespread is the idea that we live in an urban age. The watershed year of 2007, when for the first time more than half of the world's population lived in cities (UN-DESA-PD, 2014), marks for many the final triumph of urbanization, a credo echoed almost universally and not without uncritical emphasis (on this, see Brenner and Schmid, 2014).

This has profound implications. All dominant environmental visions, such as "resilience" or "sustainability," are based on the idea that the future of the planet, including humans and non-humans, depends on what will happen in and to cities, not least because of the impacts of urban networks on the Earth system. Increasingly, it is becoming impossible to speak of "the environment" without putting at center stage "the urban" - originating imaginaries and agendas radically different to those that animated modern environmentalism. Hand in hand with this urban focus, the local scale has firmly established itself as one of the privileged terrains for acting on socio-ecological problems and towards planetary sustainability.

The Anthropocene and urbanization, especially if considered together, undeniably herald big changes on the horizon. It is hard to dispute that, in one way or the other, "we are in a new political era, in which futurity is conditioned by the consequences of a changing planet" (Derickson and MacKinnon, 2015, p. 304). However, making sense of what it means to be part of the becoming of a planetary, urban and geologically powerful civilization is not straightforward. Once the sensationalism and fears stirred by the idea of a new époque have settled, a series of (old) qualms emerge: does it make any sense to speak of a "geology of mankind" (Crutzen, 2002), when we know all too well that the responsibilities, burdens, and benefits associated to global environmental changes are far from equally distributed? And can we really understand urbanization "merely" in terms of the modern city-form colonizing the whole planet? Moreover, what are the scales and forms of political action through which the tensions, 
conflicts, and transformations (in one word, the politics) of an urbanized planetary Anthropocene will unravel? With these dilemmas as starting point, this chapter raises and considers together two specular questions: What are the significance and import of the Anthropocene for urban environmental politics? And what are the role and limits of local urban interventions and initiatives in the unraveling of the politics of the Anthropocene?

The first part of the chapter offers a theoretically informed glance at how the notions of the Anthropocene and of urbanization are understood and put in dialogue in contemporary critical geographical thought. In particular, drawing on urban political ecology (henceforth UPE), we will argue that the dislocation of the binaries society/nature and rural/urban is a necessary condition for an understanding of the intertwined politics of the Anthropocene and urbanization. The second part of the chapter looks at a selection of initiatives that contain the seeds of contrasting forms of urban environmental politics in the Anthropocene. As we will see, the blurring of the natural/human divide and the challenges linked to a planetary urbanization can have contrasting political outcomes. On one end of the spectrum, mainstream initiatives (and in particular, neoliberal responses to climate change) including the construction of eco-cities, experimentations in the networking, management and governance of urban infrastructures, and the expansion of market environmentalism - seem to offer "more of the same," resembling what Alain Badiou describes as "a gigantic operation in the depoliticization of subjects" (2008, p. 139). At the other end, a number of emerging initiatives seek to imagine and enact alternative urban socio-ecological configurations, experimenting with the conditions of the Anthropocene. What is left to be seen is the ability of those alternative initiatives to transcend their local dimension in order to counter the structural conditions and processes that sustain hegemonic socio-ecological relations.

\section{THE ANTHROPOCENE: CAPITALOCENE, OLIGANTHROPOCENE, METROPOCENE, OR ASTYCENE?}

The concept of the Anthropocene has generated lively debates across natural and social sciences (for a review of human geography engagements with the notion, see Castree, 2014; Johnson et al., 2014). For sure, the concept has provided scientific grounds, as well as a conceptual and aesthetic vocabulary to the widespread sense that the impacts of human activities have undergone a "great acceleration" (Steffen et al., 2015), reaching a magnitude and scope able to shape the very future of the Earth system (for a critical introduction to the concept, see Lövbrand et al., 2009). The Anthropocene offers a sociohistorical framing to understand global environmental change and could represent a platform for environmental politics (Dalby, 2007, 2013). It offers, in other words, an intelligible and compelling narrative weaving together key epistemological, political, and normative concerns.

What lies behind the success of the concept, however, also makes it an easy target for critics. To begin with, the idea that the Anthropocene marks the beginning of "a geology of mankind" (Crutzen, 2002 ) is controversial. Although the socio-environmental transformations linked to the Anthropocene are planetary in scale, neither their causes nor their consequences are equally distributed and 
experienced (Swyngedouw, 2014; Derickson and Mackinnon, 2015). The same goes for the ability to influence environmental politics and to enact socio-ecological visions. Creating bridges across the myriads of differential positions without evacuating their politics has been a key challenge for critical theory and emancipatory politics, but is something that a discourse in the name of "mankind" seems unlikely to deliver. Indeed, the Anthropocene has been criticized for "universaliz[ing] the white liberal human subject of the Enlightenment" (Caluya, 2014, p. 41) and de-historicizing and flattening the tangle of power relations from which the Anthropocene (as condition and as concept) has emerged. Many are concerned that the quasi-eschatological emphasis on the Anthropocene as epochal, planetary rupture can obscure the driving forces behind the "great acceleration" (basically, Western industrialization and capital, rather than "mankind"), and the fact that not everybody on the planet has had the same role in the story (Malm and Hornborg, 2014; Moore, 2014; Collard et al., 2015; Haraway, 2015). Capitalocene and Oliganthropocene - the variations polemically proposed by Jason Moore and Erik Swyngedouw - epitomize well such concerns.

As much as it is said to be the "age of mankind," the Anthropocene is a discourse about an urban planet. As captured by Swyngedouw, "the Anthropocene has arrived. . and planetary urbanization is its geographical form" (Swyngedouw, 2014). A series of interventions have highlighted the essential interconnectedness between the Anthropocene and "the urban," and this linkage has titillated the creativity of geographers. While Ljungkvist et al. qualify the term further and speak of the "urban Anthropocene" (2010), Mark Whitehead coined the term "Metropocene" to describe the new socio-ecological and geological époque as "a period defined by the dynamics and demands of urbanization" (2014, p. 100). In a similar vein, Seto et al. (2010) proposed the Greek-inspired neologism

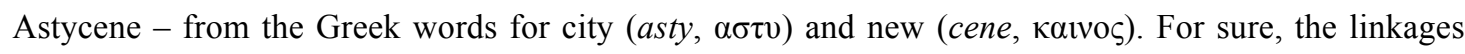
between the Anthropocene and urbanization are multiple and deep, not least because of the centrality that urban networks have had in the planetary "scramble" the Anthropocene speaks of.

To begin with, the social, economic, and spatial transformations that have "caused" the Anthropocene are inextricably linked to the trajectory of rapid urbanization that has characterized the last two centuries or so. While the emergence of the Anthropocene is explained, depending on intellectual leanings, in relation to colonialism, industrialization, development, globalization, fossilfueled capital accumulation (or most often a combination thereof), all of these processes came hand in hand with an irresistible drive towards urbanization.

The link between urbanization and the Anthropocene has also significant quantitative dimensions. For instance, urban areas and their inhabitants are cast as a key driver of anthropogenic climate change, being responsible for up to 75 percent of global carbon emissions and energy consumption more generally (Hodson and Marvin, 2010; see also Chapter 8 in IPCC, 2014); urbanization processes are also at the core of other socio-ecological transformations such as biodiversity loss, soil erosion, deforestation, pollution, and the never-ceasing commodification of all manner of natures. The other side of the coin is that urban populations are among the most exposed to the perilous sides of the Anthropocene. Indeed, cities and urban dwellers are also portrayed as the prime "victims" of some of the fiercest impacts of environmental and climate change. Drawing again on the example of 
climate change, recent years have seen a growing attention to the vulnerability of urban populations, not least in the Global South (IPCC, 2014). Quite emblematically, the stereotypical victim of climate change is migrating - not only symbolically - from the countryside (with the "traditional" image of the peasant whose livelihood is eroded by environmental changes) to the city - epitomized by the inhabitant of a slum in the Global South exposing her vulnerability every time an ever more frequent extreme weather event strikes (Bettini, 2014).

At the same time, cities and/or alternative forms of urbanism are at the epicenter of public and private investments under the banner of environmental sustainability. Starting from a very mundane datum, in the Global North almost half of the total public budget for environmental and ecological goals is spent through municipalities (Whitehead, 2014). The "green" or "sustainable" city takes a leading role within manifold discourses ranging from proclamations around "green capitalism" and "market environmentalism" (see Bailey and Caprotti, 2014) through planning and policy interventions (UNHabitat, 2006, 2011) to a series of heterogeneous and possibly anti-systemic initiatives (North, 2010). As Angelo and Wachsmuth observe "these two ideas have tripped along hand in hand: if more than half of the world is now urban, hopes for its future must rest on the shoulders of the green, sustainable city" (2015, p. 16). Put in simplistic terms, if anything new is to emerge, it is going to have to deal with the question of the "urban."

\section{GEOGRAPHICAL RUPTURES IN THE ANTHROPOCENE}

As many scholars have argued, the Anthropocene hypothesis calls for a radical rethinking of some of the analytical categories that inform environmental theory and praxis. As we will see below, taken together, the questions of the Anthropocene and urbanization highlight the links between the nature/society and rural/urban binaries (crucial in a series of geographical debates), and at the same time push them to the limit. Dislocating and overcoming the nature/society binary has a lot to do with the reshaping of the urban/rural dialectic brought about by urbanization. This at least for two reasons: first, because the two binaries are not conceptually independent - traditionally, human and urban support each other in their definition as the other to rural and natural; second because both binaries have proved to represent an obstacle to the emersion of radical agendas.

\section{Neither Natural Nor Human}

One of the most important challenges the hypothesis of the Anthropocene brings forward is that it calls for a rethinking of the ontological divide between "nature" and "society." In the words of Dipesh Chakrabarty, for example: "the anthropogenic explanations of climate change spell the collapse of the age-old humanist distinction between natural history and human history" (2009, p. 201). Significantly, one of the most prominent examples of this distinction is the dominant ways in which the relations between nature and the urban were addressed up until the early 1990s. David Wachsmuth (2012) cites the opening passages of Luis Wirth's groundbreaking essay "Urbanism as a way of life" as a paradigmatic example of accounts that treated cities and nature as strictly distinct: "[N]owhere has 
mankind [sic] been farther removed from organic nature," Wirth writes, "than under the conditions of life characteristic of great cities" (1938, pp. 1-2). In other words, cities used to represent the quintessential other to nature. At the same time, the "evaporation" of nature and of the nature/society binary has been symptomatized by the extinction of non-humanized (rural) spaces resulting from urbanization. ${ }^{1}$

Social scientists drawing from a variety of disciplinary perspectives have sought to challenge understandings of Nature as an "external conditioning sphere of human existence" (Ernstson and Swyngedouw, 2015, p. 4). Slavoj Žižek's contention that “nature does not exist” (1991) is just a prime provocative - example of a series of interventions that point to the slippery and ultimately unfixable meaning of the concept of Nature and of the nature/society divide (Morton, 2007). Of course, this does not mean that human life is finally decoupled from natural/material constrains, nor denies the scope of non-human agencies (Clark, 2011). Rather, what the intensity and reach of human activities unveils is the increased entanglement of humans and non-humans, and the fading of the distinction between the two - something Bruno Latour's work has highlighted more than two decades ago (1993, 2004). According to Latour, Nature and Culture (or Society) do not exist outside the discursive practices that produced the binary in the first place. Rather, for him, the world consists of ever multiplying socionatural quasi-objects: human and non-human assemblages that are nature-society hybrids. Jane Bennett has more recently extended these arguments suggesting such socio-natural things as "vibrant matter" that exercise their own influence in shaping socio-ecological dynamics, relations, and politics (2010).

Within urban studies, David Harvey's influential contention that "there is nothing unnatural about New York City" (Harvey 1996, p. 186, original emphasis) is a good emblem for such perspectives. Building on the work of Bruno Latour and Donna Harraway, Erik Swyngedouw has mobilized the notion of socio-natures to argue for an understanding of the urban as the field in which the nature/society dichotomy evaporates, in turn dissolving the clear opposition between city and nature (1996). Borrowing from Swyngedouw, "[i]n the city, society and nature, representation and being are inseparable, integral to each other, infinitely bound-up, yet simultaneously this hybrid socio-natural 'thing' called the city is full of contradictions, tensions and conflicts" (1996, p. 65).

Viewed through this lens, the question of the Anthropocene can therefore have extremely farreaching impacts on the conceptualization of the "urban" and of cities. Cities cease to be viewed as "places where nature stops" (Hinchliffe, 1999, p. 138). The emphasis, thus, moves to a reconceptualization of "urbanization itself as a process of socionatural and not only social transformation" (Angelo and Wachsmuth, 2015, p. 18). Here, the analytical gaze turns on how socio-natural hybrids are continuously assembled, disassembled, and re-assembled, forming simultaneously physical and social, relatively stable, quasi-objects (Castree, 2003; Braun, 2006). The terms of the question of environmental politics also shift. As Castree and Braun argue: "The crucial issue therefore, is not that of policing boundaries between 'nature' and 'culture' but rather, of taking responsibility for how our inevitable interventions in nature proceed-along what lines, with what consequences and to whose benefit (1998, p. 34). 


\section{Neither "urban" nor "rural": beyond modern urbanism}

As anticipated, the binary urban/rural and the opposition of the two as separated spatial configurations have been problematized by a number of geographical interventions (see, for instance, Castells, 1977; Lefebvre, 2003; Brenner and Schmid, 2014, Merrifield, 2014).

We cannot delve into the details of this debate here. What we briefly want to unpack instead is the question of what happens to the idea of an urban Anthropocene if we take seriously the critiques against the rural/urban dichotomy. For sure, it means taking some distance from the sort of urbanization fetishism alluded to by Brenner and Schmid (2014) - which to an extent permeates also a series of interventions on cities and the urban in the Anthropocene. Simultaneously, the idea that "humanity" is entering an "urban age" or a phase of planetary urbanization, is susceptible to critiques similar to the reservations against the Anthropocene illustrated above (in particular, those on the idea that "humanity" as a whole is impacting the Earth system; for a review of the literature around the planetary urbanization thesis and critiques to it from a post-colonial feminist perspective see Derickson, 2014). Such critiques indicate that what we see on the horizon is not a "planetary city" in the sense of the modern, Western city-form (with its peculiar forms of economic, ecological and political interactions, inclusions and exclusions) conquering the whole Earth. When taken together, the critiques to the Anthropocene and planetary urbanization help to "de-fetishize" the two concepts but do not imply a downsizing of the significance of the ruptures they point to. Quite the opposite, the urbanization-Anthropocene couple with its profound strains - can be seen as the symptom of a definitive transition away from something past: the abandonment of a series of spaces and relations between spaces (as for the modern rural-urban divide), ways of life and environments.

\section{Urbanization as Circulation and Metabolism}

In further exploring this transition, the notions of circulation and metabolism, as developed within the field of urban political ecology, can help us transcend the urban/rural binary. Indeed the concepts of circulation and metabolism suggest a reading of urbanization as "a process of de-territorialization and re-territorialization through metabolic circulatory flows" (Swyngedouw, 2006, p. 106), offering a different angle through which the "urbanization of the Earth" can be analyzed. At the level of the city as a spatial form, as Matthew Gandy argues, "the production of urban nature is inseparable, for example, from the development of urban technological networks which served to bind the modern city into a more integrated spatial form" (Gandy, 2006, p. 67). More broadly, metabolic and circulatory processes are not confined within the limits of the city. Rather, they are "linking places, and the humans and nonhumans within these places, in uneven and contingent ways" (Cook and Swyngedouw, 2012, p. 1968) with cities and peoples across the globe through socio-technical networks (Graham and Marvin, 2001) and circulatory flows. Thus, the emphasis on circulation and metabolism foregrounds an understanding of the city as product of a "metabolic socio-environmental process that stretches from the immediate environment to the remotest corners of the globe" (Heynen et al., 2006, p. 5). 
What Local Place For Planetary Politics?

The question of the Anthropocene and the ontological, epistemological, and socio-spatial transformations it signifies (with the evaporation of the nature/society divide and the question of what a planetary urbanization means), have destabilizing and potentially productive effects in the field of environmental politics too. To be sure, a synthesis of the planetary and local dimensions of the Anthropocene and urbanization has not yet been found. The combination of the local, urban, and planetary articulated in a series of contemporary political projects risks having paralyzing effects. As it has been, time and again, documented by research on urban politics, urbanization, as the transformation of socio-natures, can produce "urban environments [that] are drenched in uneven power relations" (Heynen, 2014, p. 600). For instance, the role of global cities in producing precarious life conditions and inequality (Davis, 2006), as well as "expulsions" (Sassen, 2014) is well documented. On the other hand, as Nik Heynen has recently argued, thinking of urbanization as the transformation of socionatures foregrounds an "egalitarian potential" (2014, p. 599). At the core of this potential is the claim that in order to address problems like environmental justice, pollution, and so on, wider changes to the socio-economic and cultural policing of the urban are necessary (see also Angelo and Wachsmuth, 2015).

Not surprisingly then, a number of diverse actors in environmental politics, ranging from politico-economic elites, through environmental NGOs to grassroots activists, have over the past 20 years posited the (urban) local as the privileged terrain for achieving more sustainable - and for some also more equitable - socio-environmental futures (Marvin and Guy, 1997; Lawhon and Patel, 2013). For a number of reasons, the response to challenges increasingly understood as planetary has often been articulated as local. But what does the local scale mean for environmental politics? Geographical debates over the notion of scale have since the early 1990s insisted that scale should not be viewed as a pre-given, naturally defined container in a nested hierarchy, but rather as a socially constructed and relational category that becomes temporarily fixed through power relations played out in scalar politics (Smith, 1992). With regards to urban environmental politics in particular, as Swyngedouw and Heynen suggest, "[t]he continuous reorganisation of spatial scales is an integral part of social strategies to combat and defend control over limited resources and/or a struggle for empowerment" (2003, p. 913). In other words, "it is often not scale per se that is the prime object of contention, but rather specific processes and institutionalized practices that are themselves differentially scaled" (MacKinnon, 2011, p. 21). Brown and Purcell effectively summarize: "the social and ecological outcomes of a given scalar arrangement are not to be divined in the scales themselves, but in the political agendas of the actors and organisations that produced and are empowered by the arrangement" (2005, p. 608).

There is, thus, no socio-ecological and geographical scale that is a priori more important in achieving certain goals. Rather than prioritizing the local (or any other) scale as the scale for environmental politics then, theoretical and political endeavors towards a more sustainable environment need to unpack the political processes through which specific scales of environmental problems and actions are constituted and reconstituted; the possibilities, limitations, and questions that are so highlighted or obscured; and the power relations (re-)produced (Swyngedouw and Heynen, 2003; 
Lawhon and Patel, 2013). At the same time, however, thinking of urban metabolism as a process that extends well beyond the limits of the city, brings to the forefront the significant challenges faced by urban responses to the Anthropocene imagined and practiced as local ecological enclaves. These challenges will emerge in the following section, when exploring a selection of initiatives that tackle the challenges posed by the Anthropocene with a key positioning in the urban.

\section{URBAN PRAXIS IN THE METROPOCENE}

Armed with the conceptual provocations discussed in the previous sections, we will now look at how the predicament that achieving a more green and sustainable future is an urban question has been translated into practice. The bottom line of the above discussions serves as the starting point for the following: all "the stuff" (networks, infrastructures, metabolisms, imaginaries, etc.) that make possible and sustain the existence of "the urban" have profound effects on the planet, which in turn are reconfiguring the planetary socio-ecological context wherein cities are being reproduced (Luke, 2003). Indeed, over the past years increasing attention is paid to urban environmental problems on the part of policy-makers, architects, planners, and a variety of non-governmental and citizens' organizations as well as urban movements. Reversing the terms, the governance of urban spaces has increasingly been structured around and justified on the basis of the need to "become green" - a "need" related both to ecological and economic sustainability (on this, see Holgersen and Malm, 2015). The following sections provide a brief overview of the major characteristics of recent paradigmatic urban experiments in responding to these problems. In doing so, we first focus on responses that are largely scripted along techno-managerial lines of greening capitalism to then look at alternative struggles and initiatives.

\section{"More of the Same": Neoliberal Urbanization, Green Capitalism}

Over the past years, the mantra of (mainstream) urban policy and practice has become the quest for a "solution" that would enable the mitigation of, and adaptation to, environmental despoliation through the harmonious interaction between people, the environment, and the markets. Commonly articulated around signifiers like sustainable, smart, resilient, zero-carbon, and eco-cities, a number of initiatives seek to engineer the delicate balance between humans, non-humans, and the environment through the design of technological and institutional innovations. While there is considerable variation between the proposed blueprints as well as debate between their pioneers, we can nonetheless identify some overarching tendencies (see also Keil, 2007; Swyngedouw, 2009).

First, the overarching frame that encompasses such experiments is that of market environmentalism or greening capitalism (Kenis and Lievens, 2015). As Swyngedouw has argued, the claim that the current urban environmental predicament requires serious and urgent action to make sure that cities survive is most often inscribed within the consensus that globalized capitalism is the only framework wherein such action is possible and will take place $(2009,2011)$. Such approaches, often sustained by apocalyptic tones and imaginaries, seek to green capitalist urbanization through the design of new (smart) carbon-neutral and resource-efficient eco-technologies and "best practice" governance of 
ecological problems. In other words, the ideological discourse that sustains such experiments is articulated around the nodal points of eco-technical rationality and the inscription of environmental problems within the market logic. Despite variations between different sustainability blueprints, mainstream discourses are commonly limited to debates around the best technical and institutional ways to "green" the city as well as the urgency and timeframe of their implementation (Krueger and Gibbs, 2007). As a result, the inherently political questions around possible and desirable socio-ecological futures are, more often than not, silenced and the seemingly consensual pursuit for technological and institutional eco-fixes (together with economic growth) becomes the royal way to urban sustainability (Swyngedouw, 2009).

Second, as a result of the above consensus, constructing the green and sustainable city becomes a hugely profitable market niche, opening up new avenues for capital accumulation (Castree, 2008; Himley, 2008). Of course, collectively produced urban socio-ecological assemblages have always been one of the prominent terrains and battlegrounds for capital accumulation. Yet, the current consensual quest for urban sustainability has expanded the frontier of commodification to a vast new area of socionatures. The most telling examples of this investment in green capitalist urbanization are eco-cities (Caprotti, 2014). While many of these eco-cities still remain blueprints, several of them are under construction. These include the Masdar City in Abu Dhabi that claims to be the world's first fully sustainable city (Caprotti and Romanowicz, 2013; Cugurullo, 2013), eco-island developments in San Francisco Bay (Joss, 2011), and the over 100 eco-city projects throughout China (Wu, 2012). Articulated around visions of market-based technological fixes to socio-ecological problems such projects stand as paradigmatic sites where new socio-ecological assemblages are imagined and often materialize; scripted, however, by the commodity relation and subjected to spiraling rounds of capitalist speculation (Kaika and Swyngedouw, 2011; Caprotti, 2014).

Third, the quest for ecological modernization has also been accompanied by a selective multiplication and pluralization of the actors who are involved in the production of the "green city." As Hodson and Marvin observe concerning a series of eco-urbanism projects "[a] pattern starts to emerge within which particular coalitions of social interests - consultancies, architects and engineers sometimes with elements of the green movement - are collaborating with particular place-based interests in the development of new infrastructural fixes" (2010, p. 303). This reflects a general trend wherein nonelected actors like experts, managers, and private capital are becoming integral in designing, financing, producing, and governing sustainable cities (Swyngedouw, 2009).

Fourth, an array of recent urban responses and solutions to "environmental problems" seem to be articulated around an understanding of cities as "experimental sites" (Evans, 2011; Bulkeley and Castán Broto, 2013; Rapoport, 2014). While paradigmatically encapsulated in eco-cities, this rationale also informs what Hodson and Marvin describe as "integrated eco-urbanism": a series of responses that "cut across multiple infrastructure networks - energy, food, water, waste, etc. - and that are rebundled together at particular scales in the design of new buildings, neighborhoods, towns, blocks and cities" (Hodson and Marvin, 2010, p. 303). Such experiments seek to achieve resilience and sustainability through a reduction of the dependence on external resources for the respective unit of intervention. In 
doing so, they rest on an understanding of the city "as laboratory, as an empty and bounded container" wherein architectural, technological, and socio-economic reforms are to be trialed (Caprotti, 2014, p. 1286).

Finally, and perhaps more importantly, as a result of the articulation of the above elements the political and social aspects of the city/nature nexus are silenced, reducing the urban to a stage for the interplay of technological and governance innovation and green capitalism. On the one hand, questions of socio-ecological justice and equality are largely downplayed and patterns of unequal access to and control of socio-ecological assemblages along class, gender, race, and ethnic lines are reproduced. On the other, the opportunities for dissent and contestation about possible and more radical futures are severely curtailed (Swyngedouw, 2009). Yet, the always contingent suturing of political antagonism is challenged by manifold urban socio-ecological struggles and contestations (Heynen, 2006; Loftus, 2012) that re-politicize the urban through a variety of tactics of resistance and imaginings of alternative urban socio-environmental practices. This is what we shall turn to next.

\section{Imagining Alternative Urban Communities?}

There is now, also, a growing number of initiatives that experiment with the urban politics of the Anthropocene by seeking to imagine and practice socio-ecological relations along more just, ethical, and inclusive lines while also remaining decidedly local.

The Transition Town network and the LILAC co-housing community can be seen as examples of such approaches in the UK. The rapidly growing network of Transition Towns across the UK seeks to localize food and energy supplies in an effort to move towards (urban) local resilience (Bailey et al., 2010; Mason and Whitehead, 2012). The overarching aim of the Transition Town network is to foster urban resilience by facilitating community-led responses to peak-oil and climate change (Transition Network, 2012). Re-localization or "eco-localization" (North, 2010) are thus at the core of transition initiatives; they are pursued through practices of community empowerment and deliberative democracy in the footsteps of "eco-pragmatist traditions that emphasize the power of local communities to provide the skills and resources they need for their survival" (Mason and Whitehead, 2012, p. 496).

The LILAC cohousing project based in Bramley, West Leeds provides a smaller-scale example of progressive efforts towards locally reworking socio-ecological relations (Chatterton, 2013). LILAC stands for Low Impact Living Affordable Community and consists of 20 households and a common house. The project - founded in 2009 and completed in 2013 - is a pioneering affordable, ecological cohousing experiment. LILAC seeks to articulate a grassroots, informal and community-led approach to low-carbon governance through experimenting with low impact and post-carbon living in practice (ibid.). LILAC is one of the many experiments around Low Impact Developments (LIDs) that seek to internalize resource flows and infrastructures (Pickerill and Maxey, 2009).

There are at least two key elements differentiating alternative eco-localization initiatives from hegemonic eco-urbanism projects following the predicaments of green capitalism. First, rather than depending solely on techno-managerial fixes, eco-localism puts particular emphasis on community empowerment, deliberative democracy, and experimental participation, trying to create space for 
grassroots energies and engagements to flourish. In doing so (and we come to the second point) by focusing on hands-on, community-centered, and low-cost living solutions, they promise to challenge neoliberal logics, not least in relation to accumulation for accumulation's sake (see also North, 2010). They may contain the potential for imagining and enacting alternative socio-ecological relations locally, while their networked character may allow them to create links between different places and extend their geographical reach. They can thus be seen as forms of "progressive localism" that can contribute to the construction of political alternatives (Featherstone et al., 2012).

This being said, such experiments leave a number of crucial questions unresolved. To begin with, the extent to which they manage to operate epistemic and practical ruptures with dominant forms of eco-urbanism described above is not clear. For instance, in spite of their involvement in networks, their scale of intervention remains local and self-enclosed - be that the eco-block, eco-neighborhood or eco-town. As Hodson and Marvin observe, their "emphasis on autonomy, the development of local technologies, circular metabolisms and the aspiration for greater self-reliance" $(2010$, p. 307) is quite similar to hegemonic market and state-driven forms of eco-urbanism. This is not to assimilate such progressive initiatives with neoliberal "more of the same" responses, but nonetheless calls for caution.

What is more, eco-localist initiatives show controversial stances in relation to "politics." For instance, Transition Town actively distances itself from traditional political factions and ideologies, but it does so with the pretention to assume an "apolitical stance." The question of what to do with the structural context and forces within which local experiments are unfolding is rarely addressed. This risks representing an escape from political confrontation (Kenis and Lievens, 2014; Kenis and Mathijs, 2014), and a flight from the question of whether local sustainability can be achieved in tandem or in parallel with the development of market economies and global competitiveness. On the one hand, this obscures questions of power relations reducing environmental politics to an ethical injunction (Žižek, 2008). On the other, it also occludes "questions of international responsibility and justice" that become even more pertinent when a narrow focus on the Global North is abandoned (Lawhon and Patel, 2013, p. 1048).

\section{CONCLUSIONS}

This chapter has attempted to combine two specular questions that stem from key signifiers in contemporary environmental politics and geographical thought, namely the Anthropocene and urbanization. We have explored what the hypothesis of the Anthropocene means for urban environmental politics, and in turn reflected on whether urban and local initiatives can represent the terrain for the unraveling of a politics of the Anthropocene. Along this path, the chapter encountered a series of conceptual challenges and qualms - for instance, related to the very definition of what it means to live in a planetary urban age, and the degree to which it is meaningful to speak of a "geology of mankind." Drawing on a series of geographical contributions, most notably by scholars close to the UPE current, we have argued that the dislocation of the intertwined nature/society and rural/urban 
binaries is a necessary condition in order to start grasping the analytical and political challenges posed by the two questions above.

For sure, the strains the Anthropocene puts on cities and the transformations entailed by urbanization signal big changes in the texture of urban spaces and in urban policy and initiatives. Indeed cities are increasingly becoming the terrain of experimentation. By looking at a selection of initiatives on the ground, we have seen the signs of different political projects emerging. On the one hand, despite rhetoric of epochal change and urgency, mainstream visions and projects around sustainable or green cities offer little more than "more of the same." Despite the claim that such city-based initiatives will ignite change towards planetary sustainability, they continue to be largely scripted along technomanagerial lines of green capitalism. These forms of depoliticized eco-urbanism are becoming more than ever a terrain of (speculative) capital accumulation.

On the other hand, the chapter explored a few alternatives that respond to the pressing challenges posed by the Anthropocene by imagining and materializing different socio-ecological practices. Initiatives such as Transition Towns attempt to produce experimental, deliberative, and hands-on movements that create and mobilize communities, showing significant discontinuities with mainstream, neoliberal visions and projects for the city in the Anthropocene. It is too early to know whether such discontinuities will mature into a politicized capacity to escape the logics that fuel (green) capitalism and to solidify its still embryonic practices.

It remains to be seen whether mainstream or alternative forms of urban "Anthropocenic" politics will become predominant, and it can be expected that a good amount of attrition (and struggles) will have to do with the "clash" between these two approaches. Maybe even more pressing is the question of the extent to which the local/urban alone can represent the terrain for politics in the Anthropocene. As we have seen, there is an unresolved tension between the local character of urban initiatives and the planetary (and structural) conditions and processes that keep in motion the Anthropocene and urbanization (and that have to be acted upon if any substantial change in dominant socio-ecological relations is to be brought about). Whether the local will represent the terrain for the take-off of new socio-ecological experiments, or it will represent a depoliticized escape from political confrontation (to the advantage of dominant relations) is still to be seen.

\section{NOTE}

1.There is of course a long history of thinking about the relations between cities and nature to which we cannot do justice here. Schematically, as Wachsmuth details through an account of the discussion of the city/nature relations in three paradigms in urban theory (the Chicago School of human ecology, industrial ecology, and urban political ecology), it can be suggested that in twentieth-century urban theory: "[n] ature begins as entirely absent from the city, proceeds to inhabit its outside, and ends up profoundly implicated in its production and reproduction" (2012, p. 507). This does not mean that there was a linear transition from one understanding to the other; moreover, there were notable exceptions, such as Lewis Mumford, who sought to move beyond the dichotomy (Braun, 2005). 


\section{REFERENCES}

Angelo, H. and D. Wachsmuth (2015), "Urbanizing urban political ecology: a critique of methodological cityism," International Journal of Urban and Regional Research, 39 (1), 16-27.

Badiou, A. (2008), “Live Badiou: interview with Alain Badiou, Paris, December 2007," in O. Feltham (ed.), Alain Badiou: Live Theory, London: Continuum, pp. 136-9.

Bailey, I. and F. Caprotti (2014), "The green economy: functional domains and theoretical directions of enquiry," Environment and Planning A, 46 (8), 1797-813.

Bailey, I., R. Hopkins and G. Wilson (2010), "Some things old, some things new: the spatial representations and politics of change of the peak oil relocalisation movement," Geoforum, 41 (4), 595-605.

Bennett, J. (2010), Vibrant Matter: A Political Ecology of Things, Durham, NC: Duke University Press.

Bettini, G. (2014), "Climate migration as an adaption strategy: de-securitizing climate-induced migration or making the unruly governable?" Critical Studies on Security, 2 (2), 180-95.

Braun, B. (2005), "Environmental issues: writing a more-than-human urban geography," Progress in Human Geography, 29 (5) 635-50.

Braun, B. (2006), "Environmental issues: global natures in the space of assemblage," Progress in Human Geography, 30 (5), 644-54.

Brenner, N. and C. Schmid (2014), “The 'urban age' in question,” International Journal of Urban and Regional Research, 38 (3), 731-55.

Brown, J.C. and M. Purcell (2005), “There's nothing inherent about scale: political ecology, the local trap, and the politics of development in the Brazilian Amazon," Geoforum, 36 (5), 607-24.

Bulkeley, H. and V. Castán Broto (2013), "Government by experiment? Global cities and the governing of climate change," Transactions of the Institute of British Geographers, 38 (3), 361-75.

Caluya, G. (2014), "Fragments for a postcolonial critique of the Anthropocene," in J. Frawley and I. McCalman (eds), Rethinking Invasion Ecologies from the Environmental Humanities, New York: Routledge, pp. 31-44.

Caprotti, F. (2014), "Eco-urbanism and the eco-city, or, denying the right to the city?" Antipode, 46 (5), 1285-303. Caprotti, F. and J. Romanowicz (2013), “Thermal eco-cities: green building and urban thermal metabolism," International Journal of Urban and Regional Research, 37 (6), 1949-67.

Castells, M. (1977), The Urban Question: A Marxist Approach, London: Edward Arnold.

Castree, N. (2003), "Environmental issues: relational ontologies and hybrid politics," Progress in Human Geography, 27 (2), 203-11.

Castree, N. (2008), "Neoliberalising nature: the logics of deregulation and reregulation," Environment and Planning A, 40 (1), 131-52.

Castree, N. (2014), "Geography and the Anthropocene II: current contributions," Geography Compass, 8 (7), 45063.

Castree, N. and B. Braun (eds) (1998), "The construction of nature and the nature of construction," in Remaking Reality: Nature at the Millennium, New York: Routledge, pp. 3-42.

Chakrabarty, D. (2009), “The climate of history: four theses,” Critical Inquiry, 35 (2), 197-222.

Chatterton, P. (2013), "Towards an agenda for post-carbon cities: lessons from LILAC, the UK's first ecological, affordable cohousing community,” International Journal of Urban and Regional Research, 37 (5), 1654-74.

Clark, N. (2011), Inhuman Nature: Sociable Life on a Dynamic Planet, London: Sage. 
Collard, R.C., J. Dempsey and J. Sundberg (2015), “A manifesto for abundant futures," Annals of the Association of American Geographers, 105 (2), 322-30.

Cook, I.R. and E. Swyngedouw (2012), "Cities, social cohesion and the environment: towards a future research agenda," Urban Studies, 49 (9), 1959-79.

Crutzen, P.J. (2002), “Geology of mankind," Nature, 415 (6867), 23.

Crutzen, P. and E. Stoermer (2000), “The Anthropocene,” Global Change Newsletter, No. 41, May.

Cugurullo, F. (2013), "How to build a sandcastle: an analysis of the genesis and development of Masdar City,"

Journal of Urban Technology, 20 (1), 23-37.

Dalby, S. (2007), “Anthropocene geopolitics: globalisation, empire, environment and critique,” Geography Compass, 1 (1), 103-18.

Dalby, S. (2013), "Biopolitics and climate security in the Anthropocene," Geoforum, 49, 184-92.

Davis, M. (2006), Planet of Slums, London: Verso.

Derickson, K.D. (2014), “Urban geography I: locating urban theory in the 'urban age'," Progress in Human Geography, 0309132514560961.

Derickson, K.D. and D. MacKinnon (2015), “Toward an interim politics of resourcefulness for the Anthropocene,” Annals of the Association of American Geographers, 105 (2), 304-12.

Ernstson, H. and E. Swyngedouw (2015), "Framing: rupturing the Anthroobscene! The political promises of planetary and uneven urban ecologies," position paper at the Conference at Teater Reflex 16-19 September organized by KTH Environmental Humanities Laboratory, Stockholm.

Evans, J.P. (2011), "Resilience, ecology and adaptation in the experimental city," Transactions of the Institute of British Geographers, 36 (2), 223-37.

Featherstone, D., A. Ince and D. Mackinnon et al. (2012), "Progressive localism and the construction of political alternatives," Transactions of the Institute of British Geographers, 37 (2), 177-82.

Gandy, M. (2006), "Urban nature and the ecological imaginary," in N. Heynen, M. Kaika and E. Swyngedouw (eds), In the Nature of Cities: Urban Political Ecology and the Politics of Urban Metabolism, London: Routledge, pp. 63-74.

Graham, S. and S. Marvin (2001), Splintering Urbanism: Networked Infrastructures, Technological Mobilities and the Urban Condition, New York: Psychology Press.

Haraway, D. (2015), “Anthropocene, Capitalocene, Plantationocene, Chthulucene: making kin,” Environmental Humanities, 6, 159-65.

Harvey, D. (1996), Justice, Nature and the Geography of Difference, Oxford: Blackwell.

Heynen, N. (2006), "But it's alright, Ma, it's life, and life only: radicalism as survival," Antipode, 38 (5), 916-29. Heynen, N. (2014), “Urban political ecology I: the urban century,” Progress in Human Geography, 38 (4), 598 604.

Heynen, N., M. Kaika and S. Swyngedouw (2006), In the Nature of Cities: Urban Political Ecology and the Politics of Urban Metabolism, New York: Taylor and Francis.

Himley, M. (2008), "Geographies of environmental governance: the nexus of nature and neoliberalism," Geography Compass, 2 (2), 433-51.

Hinchliffe, S. (1999), “Cities and natures: intimate strangers,” in J. Allen, D. Massey and M. Pryke (eds), Unsettling Cities: Movement/Settlement, London: Routledge, pp. 137-80.

Hodson, M. and S. Marvin (2010), "Urbanism in the Anthropocene: ecological urbanism or premium ecological enclaves?" City, 14 (3), 298-313. 
Holgersen, S. and A. Malm (2015), “'Green fix’ as crisis management, or: in which world is Malmö the world's greenest city?" Geografiska Annaler B, 97 (4), 275-90.

IPCC (2014), Climate Change 2014: Impacts, Adaptation, and Vulnerability. Part A: Global and Sectoral Aspects. Contribution of Working Group II to the Fifth Assessment Report of the Intergovernmental Panel on Climate Change, Cambridge, UK and New York: Cambridge University Press.

Johnson, E., H. Morehouse and S. Dalby et al. (2014), “After the Anthropocene: politics and geographic inquiry for a new epoch," Progress in Human Geography, 38 (3), 439-56.

Joss, S. (2011), "Eco-cities: the mainstreaming of urban sustainability: key characteristics and driving factors," International Journal of Sustainable Development and Planning, 6 (3), 268-85.

Kaika, M. and E. Swyngedouw (2011), "The urbanization of nature: great promises, impasse, and new beginnings," in G. Bridge and S. Watson (eds), The New Blackwell Companion to the City, Oxford: Blackwell, pp. 96-107. Keil, R. (2007), “Sustaining modernity, modernising nature,” in R. Kreuger and D. Gibbs (eds), The Sustainable Development Paradox: Urban Political Ecology in the US and Europe, New York: Guilford Press, pp. 41-65. Kenis, A. and M. Lievens (2014), "Searching for 'the political' in environmental politics," Environmental Politics, 23 (4), 531-48.

Kenis, A. and M. Lievens (2015), The Limits of the Green Economy: From Re-inventing Capitalism to Repoliticising the Present, London and New York: Routledge.

Kenis, A. and E. Mathijs (2014), “(De) politicising the local: the case of the Transition Towns movement in Flanders (Belgium)," Journal of Rural Studies, 34, 172-83.

Krueger, R. and D. Gibbs (2007), The Sustainable Development Paradox: Urban Political Economy in the United States and Europe, New York: Guilford Press.

Latour, B. (1993), We Have Never Been Modern, New York and London: Harvester Wheatsheaf.

Latour, B. (2004), Politics of Nature: How to Bring the Sciences into Democracy, Cambridge, MA: Harvard University Press.

Lawhon, M. and Z. Patel (2013) "Scalar politics and local sustainability: rethinking governance and justice in an era of political and environmental change," Environment and Planning C: Government and Policy, 31 (6), 104862.

Lefebvre, H. (2003), The Urban Revolution, Minneapolis, MN: University of Minnesota Press.

Ljungkvist, J., S. Barthel, G. Finnveden and S. Sörlin (2010), “The urban Anthropocene: lessons for sustainability from the environmental history of Constantinople," in P. Sinclair, F. Herschend, G. Norquist and C. Isendahl (eds), The Urban Mind: Cultural and Environmental Dynamics, Uppsala: Uppsala University Press, pp. 367-90. Loftus, A. (2012), Everyday Environmentalism: Creating an Urban Political Ecology, Minneapolis, MN: University of Minnesota Press.

Lövbrand, E., J. Stripple and B. Wiman (2009), "Earth system governmentality,” Global Environmental Change, 19 (1), 7-13.

Luke, T.W. (2003), “Global Cities vs. 'global cities': rethinking contemporary urbanism as public ecology,” Studies in Political Economy, 70, 11-33.

MacKinnon, D. (2011), "Reconstructing scale: towards a new scalar politics," Progress in Human Geography, 35 (1), 21-36.

Malm, A. and A. Hornborg (2014), "The geology of mankind? A critique of the Anthropocene narrative," The Anthropocene Review, 1 (1), 62-9.

Marvin, S. and S. Guy (1997), "Creating myths rather than sustainability: the transition fallacies of the new localism," Local Environment, 2 (3), 311-18. 
Mason, K. and M. Whitehead (2012), "Transition urbanism and the contested politics of ethical place making," Antipode, 44 (2), 493-516.

Merrifield, A. (2014), The New Urban Question, London: Pluto Press.

Moore, J.W. (2014), “The Capitalocene, Part I: on the nature and origins of our ecological crisis," accessed 29 June 2016 at http://www.jasonwmoore.com/uploads/The_Capitalocene_Part_I_June_2014.pdf.

Morton, T. (2007), Ecology Without Nature: Rethinking Environmental Aesthetics, Cambridge, MA: Harvard University Press.

North, P. (2010), "Eco-localisation as a progressive response to peak oil and climate change - a sympathetic critique," Geoforum, 41 (4), 585-94.

Pickerill, J. and L. Maxey (2009), "Geographies of sustainability: low impact developments and radical spaces of innovation," Geography Compass, 3 (4), 1515-39.

Rapoport, E. (2014), "Utopian visions and real estate dreams: the eco-city past, present and future," Geography Compass, 8 (2), 137-49.

Sassen, S. (2014), Expulsions: Brutality and Complexity in the Global Economy, Cambridge, MA: Harvard University Press.

Seto, K.C., R. Sanchez-Rodriguez and M. Fragkias (2010), “The new geography of contemporary urbanization and the environment," Annual Review of Environment and Resources, 35 (1), 167-94.

Smith, N. (1992), "Geography, difference and the politics of scale," in J. Doherty, E. Graham and M. Mallek (eds), Postmodernism and the Social Sciences, London: Macmillan.

Steffen, W., P.J. Crutzen and J.R. McNeill (2007), “The Anthropocene: are humans now overwhelming the great forces of nature?," $A M B I O, 36$ (8), 614-21.

Steffen, W., Å. Persson and L. Deutsch et al. (2015), “The trajectory of the Anthropocene: the great acceleration," The Anthropocene Review, 2, 81-98.

Swyngedouw, E. (1996), "The city as a hybrid: on nature, society and cyborg urbanization," Capitalism Nature Socialism, 7, 65-80.

Swyngedouw, E. (2006), "Circulations and metabolisms: (hybrid) natures and (cyborg) cities," Science as Culture, $15(2), 105-21$

Swyngedouw, E. (2009), "The antinomies of the postpolitical city: in search of a democratic politics of environmental production,” International Journal of Urban and Regional Research, 33 (3), 601-20.

Swyngedouw, E. (2011), “Interrogating post-democratization: reclaiming egalitarian political spaces,” Political Geography, 30 (7), 370-80.

Swyngedouw, E. (2014), “The violence of sustainable urbanity,” Metropolitics.eu, 10 November, accessed 29 June 2016 at http://www.metropolitiques.eu/The-Violence-of-Sustainable.html.

Swyngedouw, E. and N.C. Heynen (2003), "Urban political ecology, justice and the politics of scale," Antipode, 35 (5), 898-918.

Transition Network (2012), “Why do transition?” accessed 30 June 2016 at https://www.transitionnetwork.org/why-do-transition.

UN-DESA-PD (2014), World Urbanization Prospects: The 2014 Revision, Highlights, New York: United Nations. UN-Habitat (2006), State of the World's Cities 2006/7, New York: United Nations.

UN-Habitat (2011), Cities and Climate Change: Global Report on Human Settlements 2011, New York: United Nations.

Wachsmuth, D. (2012), “Three ecologies: urban metabolism and the society-nature opposition,” The Sociological Quarterly, 53 (4), 506-23. 
Whitehead, M. (2014), Environmental Transformations: A Geography of the Anthropocene, New York: Routledge. Wirth, L. (1938), “Urbanism as a way of life,” American Journal of Sociology, 44 (1), 1-24.

Wu, F. (2012), “China's eco-cities,” Geoforum, 43 (2), 169-71.

Žižek, S. (1991), Looking Awry: An Introduction to Jacques Lacan Through Popular Culture, Cambridge, MA: MIT Press.

Žižek, S. (2008), “Nature and its discontents,” SubStance, 37 (3), 37-72. 